\title{
Ákos Treszkai
}

\section{THE RIVER NILE CONFLICT IN THE ASPECTS OF CRITICAL INFRASTRUCTURE PROTECTION}

DOI: $10.35926 /$ HDR.2020.1.3

\begin{abstract}
The aim of this paper is to present the River Nile conflict from the aspects of critical infrastructure protection. It is often stated that the next world war will be fought over water, and there are few regions as tense as the Nile Valley. Egypt and Ethiopia have a severe disagreement, Sudan is in the middle of it, and a big geopolitical shift is being played along the world's longest river. The Grand Renaissance Dam has been under construction on the Blue Nile River in Ethiopia. This dam will be the greatest hydroelectric power plant in Africa. This critical infrastructure has both political and military importance.
\end{abstract}

KEYWORDS: River Nile conflict, critical infrastructure, Grand Renaissance Dam

\section{INTRODUCTION}

At the beginning of this review it is important to explain the definition of the critical infrastructures. Considering that critical infrastructures are a really complex issue, there are several definitions. In particular, the Ethiopian Grand Renaissance Dam has both political and military importance. The military aspect is explained by the NATO definition of critical infrastructure.

According to the NATO definition: "Critical Infrastructure is those facilities, services and information systems which are so vital to nations that their incapacity or destruction would have a debilitating impact on national security, national economy, public health and safety and the effective functioning of the government"I

The European Union's definition presents critical infrastructure mainly from political aspects:

According to the EU definition: "Critical infrastructures are those physical and information technology facilities, networks, services and assets which, if disrupted or destroyed, would have a serious impact on the health, safety, security or economic well-being of citizens or the effective functioning of governments in European Union (EU) countries"2

The above presented two definitions highlight the difference in the focus.

In short, critical infrastructures are:

- Energy installations and networks;

- Communications and information technology;

1 Khan, J. "Critical infrastructure protection within NATO". http://www.cipre-expo.com/wp-content/uploads/ 2014/02/khan-jahier-nato-cip-within-nato.pdf, Accessed on 30 Jul 2019.

2 "Communication from the Commission to the Council and the European Parliament: Critical Infrastructure Protection in the fight against terrorism: COM/2004/0702". European Union. 2004. https://eur-lex.europa.eu/ legal-content/EN/TXT/PDF/?uri=CELEX:52004DC0702\&from=en, Accessed on 30 July 2019. 
- Finance (banking, securities, and investment);

- Health care;

- Food;

- Water (dams, storage, treatment, and networks);

- Transport (airports, ports, intermodal facilities, railway and mass transit networks, and traffic control systems);

- Production, storage and transport of dangerous goods (e.g., Chemical, biological, radiological and nuclear materials);

- Government (e.g., Critical services, facilities, information networks, assets, and key national sites and monuments). ${ }^{3}$

In this review, both military and political aspects are relevant in order to understand the sensitivity of the water sharing issue and the dispute between Ethiopia and Egypt.

\section{RISK ELEMENTS IN CONNECTION WITH CRITICAL INFRASTRUCTURES}

From the aspects of critical infrastructure protection, there are different elements that affect the security of critical infrastructures. These elements are:

- double dependency;

- special operating environment;

- location;

- domino effects;

- information security;

- IT security.

Double dependency: Critical infrastructures are complex systems, and there is a significant operating dependency between the various infrastructures; furthermore, there is a dependency between critical infrastructure and society, as well.

Another risk element is the special operating environment because the operating of a critical infrastructure itself is a high-risk activity.

The location of critical infrastructures is also an important factor because human activities (such as wars and armed conflicts) or natural disasters (like hurricanes and floods) also affect the operation and the safety of critical infrastructures.

There are other factors that threaten critical infrastructures, for example, the above-mentioned domino effect. In the proper sense, the domino effect is a chain reaction, because the operation of critical infrastructures consists of complex and depending systems. If one critical infrastructure has any error, it could lead to a breakdown in other infrastructures, too.

Nowadays, information security and IT security are essential with regard to critical infrastructure protection. There is some vital and sensitive information that is cardinal in connection with safe operation. In our days, IT security is as important as physical security. In the $21^{\text {st }}$ century, a cyberattack could also be as destructive and dangerous as a physical one.

3 "Communication from the Commission to the Council and the European Parliament: Critical Infrastructure Protection in the fight against terrorism: COM/2004/0702". 
In short, safety and security comprise evidently one of the most significant factors in the operation of critical infrastructures. ${ }^{4}$

\section{A HISTORICAL EXAMPLE}

Throughout history, it has occurred several times that an enemy attacked the critical infrastructure of another enemy or group in order to cause serious damage. Various cyber and physical attacks and sabotage actions have been carried out against diverse critical infrastructures. The results of these kinds of attacks are malfunction and damage; besides, they cause panic and fear in societies, especially in the affected territories, and critical infrastructures could be targets not only of state actors but also of terrorists.

In the $20^{\text {th }}$ century, this kind of attack was relatively well documented. It is important to highlight the attacks against dams.

One of the most significant attacks happened during the Second World War. In Operation "Chastise" during the night of 16-17 May 1943, the British Royal Air Force destroyed three dams in the Ruhr valley, the territory of which was the heartland of the German industry.

The Ruhr valley had significant relevance in the German war industry. On the one hand, the water in the reservoir used to generate electricity, and on the other hand, it played a crucial role in the German war industry. The British Royal Air Force developed a special "bouncing" bomb for this purpose, which was able to destroy the dams. The British Royal Air Force targeted three dams, namely the Möhne, Eder, and Sorpe dams. The dams were burst, and it caused catastrophic floods in the Ruhr valley, and several villages were destroyed. Around 1,600 civilians lost their lives as a result of the attack on the dams. ${ }^{5}$

\section{THE IMPORTANCE OF HYDROELECTRIC POWER PLANTS FOR ETHIOPIA}

For Ethiopia, the hydroelectric power plant is of paramount importance. The country's population is currently around 107 million people, which increases by $2.3 \%$ per year. $^{6}$

The country is one of Africa's fastest-growing economies. ${ }^{7}$

In order to maintain its economic performance, the country's energy demand is increasing. As a result of the economic growth, between 2002 and 2006 electricity demand increased by $13 \%$ annually, while today it increases by approx. $20 \%{ }^{8}$

In order to cover this level of demand/growth, investments, such as the Grand Renaissance Dam are needed. The determination is shown by the fact that the dam is planned to

4 Bonnyai T. “A kritikus infrastruktúra védelem elemzése a lakosságfelkészítés tükrében”. PhD thesis. Budapest: National University of Public Service, 2014. 22-25

5 Mason A. "The incredible story of the dambusters raid". Imperial War Museums. 5 Jan 2018. https://www.iwm. org.uk/history/the-incredible-story-of-the-dambusters-raid, Accessed on 30 Jul 2019.

6 "Ethiopia population". Worldometers. http://www.worldometers.info/world-population/ethiopia-population/. Accessed on 30 Jul 2019.

7 Monteiro A. and Thukwana, N. "IMF sees Ethiopia beating Ghana as fastest-growing Africa economy". Bloomberg. 17 Apr 2018. https://www.bloomberg.com/news/articles/2018-04-17/ethiopia-pips-ghana-as-africa-s-fastest-growing-economy-for-imf, Accessed on 30 Jul 2019.

8 Mondal H. A. et al. "Ethiopian energy status and demand scenarios: prospects to improve energy efficiency and mitigate GHG emissions". Energy 149. 2018. 161-172. DOI:10.1016/j.energy.2018.02.067 
cost $\$ 4.7$ billion, which is entirely financed from the country's own budget. The size of the investment is illustrated by the fact that 8,500 workers constantly work on the construction.

The Grand Renaissance Dam is not the only hydroelectric investment in Ethiopia. Parallel to its construction, Gibe III (1870 MW) and Genela Dawa III (254 MW) dams are also being built, all of which remain below the Grand Renaissance Dam in size and output of power.

According to the official Ethiopian position, the construction of the dam provides highly mutually beneficial cooperation with the Nile countries, as this development can reduce the East African region's energy shortage, among others, and beyond cooperation in the field of electricity, further economic cooperation will form in the region.

Ethiopia will export electricity to Kenya, reducing Kenya's energy needs and reducing the environmental pollution. Under the current agreements, Ethiopia will export to Kenya, Sudan, and Djibouti. The infrastructure needed for this is being built parallel with the construction of the dam.

\section{EGYPT'S CONCERN OVER RIVER NILE}

The main source of the conflict is the Nile itself. The Nile is the longest river in the world $(6,700 \mathrm{~km})$ and crosses the East African region. One source is the Blue Nile, which originates from the Ethiopian Highlands, and this source branch has more significant water supply. The other source is the White Nile, which originates from the Central African region, including Rwanda. The two rivers meet in Sudan, near Khartoum, and continue their journey through Egypt to the Mediterranean Sea. ${ }^{9}$

There are 11 countries on the Nile: Burundi, South Sudan, Eritrea, Ethiopia, Kenya, Democratic Republic of Congo, Rwanda, Sudan, Tanzania, and Uganda.

However, the construction of the Grand Renaissance Dam is not so beneficial for all those concerned. Egypt has been firmly protesting against the construction of the dam for years. According to the Egyptian viewpoint, the Grand Renaissance Dam could significantly reduce the Nile's runoff and, as a result, even the existence of Egypt could be endangered.

It can also be seen from the above that while the runoff of the Nile is decreasing, the number of inhabitants constantly increases, so the river runoff, among other things, is a key issue. All experts agree that with the building of the dam, the Nile's runoff will be reduced, and less water will reach Egypt.

The reason for this is that the massive reservoir behind the dam has to be filled with a volume of 74 cubic kilometers and to fill this vast area, the Nile will be partially deflected, so it is expected that the water flow will drop in Sudan and Egypt. ${ }^{10}$

At the same time, if the reservoir is fully filled, it will not be able to return to its original, natural state, because through this huge water surface natural evaporation will drastically increase.

The problem is both historical and contemporary.

9 “Nile River". In Encyclopedia Britannica. https://www.britannica.com/place/nile-river, Accessed on 3 Aug 2019.

10 Molnár, Cs. “A Nagy Reneszánsz Gát”. https://molnarcsaba.wordpress.com/2018/03/22/a-nagy-reneszansz-gat/, Accessed on 3 Aug 2019. 
The historical reasons - very often in Africa - can be traced back to colonialism. The first agreement on the Nile was born in 1929 between Great Britain and Egypt. As part of the agreement, Egypt in fact has a veto on all matters concerning the Nile.

The basis for this authorization is that the Nile is the only source of fresh water in Egypt. Virtually there is no other freshwater source in Egypt. Referring to this, the Egyptian party in the current conflict voices that the Nile, for Egypt, is a vital issue.

The second agreement was signed in 1959, which already determined the amount of water that can be used by the countries concerned. According to the agreement Egypt is entitled to 55 billion cubic meters of average annual use out of the 84 billion cubic meters of the Nile. Sudan is entitled to 18.5 billion cubic meters, so basically, the rest of the countries almost barely receive from the Nile. ${ }^{11}$

In fact, in the agreements, all the other affected East African countries were ignored entirely, so in simple terms, the source of the conflict is the unfair distribution of the Nile's water. Egypt's reference is based on the two previous treaties which are not accepted by the other countries, as they have been wholly excluded from the negotiations and the agreement.

The other source of the problem, which today is a growing challenge on the whole African continent, is global warming, which can be observed as a result of global climate change.

The result of warming is drought and the lack of rainfall; the flow of rivers and lakes is continuously decreasing. It is expected that the Nile's runoff will also decrease.

In addition to climate change, another significant problem is overpopulation. Egypt's population is currently around 99 million people, ${ }^{12}$ Sudan has a population of 41 million, ${ }^{13}$ Ethiopia's population is around 107 million $^{14}$. The total population of 247 million will be around 316 million by $2030 .^{15}$

\section{THE ETHIOPIAN GRAND RENAISSANCE DAM}

Since 2011 “The Grand Renaissance Dam” has been built in Ethiopia on the Blue Nile in the Benishangul Gumaz region, which is approx. $600 \mathrm{~km}$ northwest of Addis Ababa, the capital of Ethiopia, and $40 \mathrm{~km}$ from the Sudanese border. It is planned that the dam will be the largest hydropower plant in Africa when it is completed. It will be the $7^{\text {th }}$ largest one in the world. The dam will be 1,800 meters long and 145 meters high. The power plant is expected to be able to generate 6,000 MW of electricity. By comparison, the Hungarian Nuclear Power Plant is only capable of generating one-third of this. ${ }^{16}$

11 Crabités, P. “The Nile Waters Agreement”. Foreign Affairs 8/1. 1929. 145-149. DOI:10.2307/20028752

12 "Egypt population". Worldometers. http://www.worldometers.info/world-population/egypt-population/, Accessed on 7 Aug 2019.

13 "Sudan population". Worldometers. http://www.worldometers.info/world-population/sudan-population/ Accessed on 7 Aug 2019.

14 "Ethiopia population". Worldometers. http://www.worldometers.info/world-population/ethiopia-population/. Accessed on 30 Jul 2019.

15 “Ethiopia 2030". Populationpyramid.net. https://www.populationpyramid.net/ethiopia/2030/, Accessed on 7 Aug 2019.

16 Havasi, Zs. "Enyhültek a kedélyek a történelmi beruházás körül”. Magyar Nemzet Online, 13 Mar 2015. Https://mno.hu/kulfold/enyhultek-a-kedelyek-a-tortenelmi-beruhazas-korul-1276918, Accessed on 7 Aug 2019. 


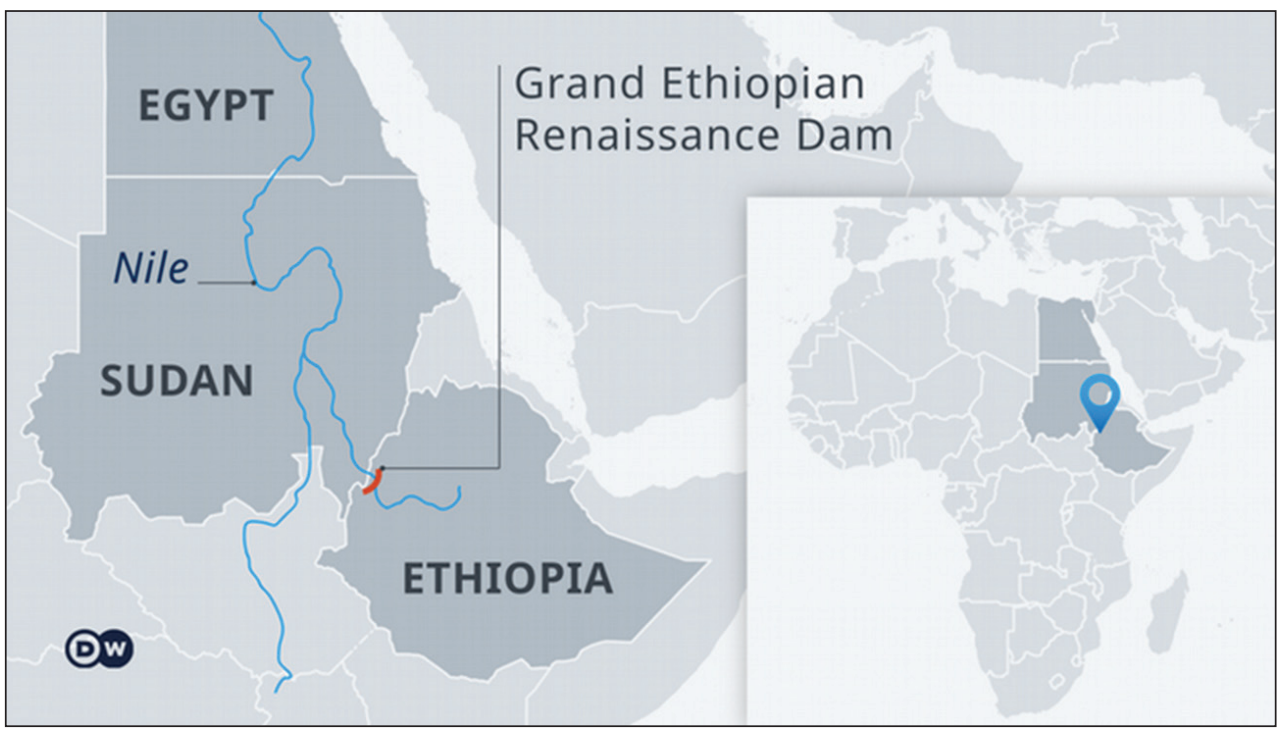

Figure 1 Map of North Africa and the place of the Grand Ethiopian Renaissance Dam ${ }^{17}$

The tension between Egypt and Ethiopia began in 2010; the worst point was in 2011 when the parties began to threaten each other more openly through their various diplomatic channels and the international media. Based on the information leaked by Wikileaks, nowadays, it is evident that beyond the diplomatic missions, the Egyptians also counted on a military operation against the dam that was built. ${ }^{18}$

Egyptians have planned three possible scenarios:

- Airstrike

- Special Operations Forces attack on the ground

- Sabotage action carried out by supported rebels

1. According to security and military experts, Egypt would not be able to carry out airstrikes against the dam. On the one hand, according to open source information, the Egyptian Air Force does not have bombers with sufficient range to be able to fly to Ethiopia without landing and to drop bombs there. Another danger of the Dam's bombing is that just like in the Second World War, when the English Air Force hit the Ruhr rural dams, it would probably result in many civilian casualties, and in addition to the diplomatic consequences, the public would also sound their opinion against them, and it could lead to political or economic isolation. Another barrier to the airstrikes is the air defense of the dam. Given that the dam under construction is a critical infrastructure that is currently the most significant

17 Mules, I. "Ethiopia, Egypt, Sudan make slow progress in Nile dam row". Deutsche Welle. https://www.dw.com/ en/ethiopia-egypt-sudan-make-slow-progress-in-nile-dam-row/a-52015611, Accessed on 7 Aug 2019.

18 Kelley, B. M. and Johnson, R. "Stratfor: Egypt is prepared to bomb all of Ethiopa's Nile dams." Business Insider, 13 Oct 2012. http://www.businessinsider.com/hacked-stratfor-emails-egypt-could-take-military-action-toprotect-its-stake-in-the-nile-2012-10?international=true\&r=us\&ir=t, Accessed on 17 Aug 2019. 
investment in Ethiopia, significant military forces have been deployed to protect it, including a considerable amount of air defense.

2. There are also many obstacles to land-based attacks by Special Operations Forces. On the one hand, just like in the case of an airstrike, there is too much distance between the two countries, and therefore it is a severe problem to get to the operation area. The other major challenge for the commando action is that dams and their surroundings in other parts of the world are protected by well-trained forces specialized in critical infrastructure protection. Therefore, blowing up a dam in action carried out by a special unit would be very difficult or even impossible. ${ }^{19}$

3. A sabotage action carried out by supported rebels as an opportunity to prevent the construction of the dam is also a possibility. A secret service operation has more realistic chances than a military action. There was some "classified" information in the reports leaked by Wikileaks that a senior Egyptian politician told an American diplomat that Ethiopia had tried to build a dam as early as 1976, but then the Egyptians blasted the ship carrying the necessary equipment to Ethiopia at sea. ${ }^{20}$

At the moment the realistic threat of a war between the two countries has ceased, and several political talks have begun to resolve the conflict, but for the time being there is no meaningful, concrete agreement on water sharing, in the narrow sense, in relation to the Grand Renaissance Dam.

In March 2017, gunmen attacked the dam with handguns and grenade launchers in the Nile. According to the Ethiopian authorities it was a sabotage action, and the Benisangul People's Liberation Movement, which enjoys the support of Eritrea, was responsible for it. In the attack, 13 attackers lost their lives, and 7 attackers were captured. ${ }^{21}$

The River Nile tension between Egypt and Ethiopia is not only a local issue. It could have international consequences that could affect the Hungarian Defence Forces as well.

There are two possible scenarios for the the Hungarian Defence Forces.

The first scenario is that in the case of a war between Ethiopia and Egypt, the international community and organizations such as North Atlantic Treaty Organization (NATO) or European Union (EU) would deploy Hungarian military and police personnel in various international missions.

The second scenario is that, the "water war" could generate a large number of displaced persons who would try to migrate to the territory of the European Union. The Hungarian Defence Forces would have a task in the protection of the Hungarian border.

\section{CONCLUSION}

To sum up, the Grand Renaissance Dam, which is being built on the Blue Nile in Ethiopia, is a critical infrastructure that has not only security but also political and economic significance. In the case of the Grand Renaissance Dam, the main and most realistic threat factor is "Acts of malicious intent, which are acts of intentional harm that may have a psychological

19 “Egypt's limited military options to stop an ethiopian dam project." STRATFOR. 10 Jun 2013. https://worldview.stratfor.com/article/egypts-limited-military-options-stop-ethiopian-dam-project, Accessed on 17 Aug 2019.

20 Kelley and Johnson. "Stratfor: Egypt is prepared to bomb all of Ethiopa's Nile dams."

21 Király A. "Lázadók támadtak az épülő Nílus-gátra Etiópiában”. https://444.hu/2017/03/02/lazadok-tamadtak-az-epulo-nilus-gatra-etiopiaban, Accessed on 17 Aug 2019. 
effect on the harm caused, especially on the companionship." 22 In this particular case, I would also mention the political, military, and economic significance of this.

As shown above, the Grand Renaissance Dam is of paramount importance to the entire East African region. There is a conflict between different interests in this issue. On the one hand, Egypt refers to the previous treaties and, in its view, still has a veto over the investments planned on the Nile, and just like in the past, it will protect every drop of the Nile's water. In contrast, in Ethiopia and Kenya, there is a very significant lack of electricity that is in the process of further development. In my opinion, if the dam is built and the reservoir starts to fill up, then the conflict will flare up again as Egypt will face a decrease in the water level and water flow of the Nile, which will also affect the agriculture, along with drinking water supply, shipping, and other factors. Besides, on the one hand, the flooding of the river will lead to a change in previous agricultural areas and on the other hand, the water supply for irrigation will decrease, which will also reduce the average yield.

The current tensions can only be solved by negotiations, and international cooperation is needed. On the one hand, if the amount of crop in Egypt is reduced, it will have to be replaced from outside sources, with imports, and on the other hand, Ethiopia will have to do everything in the future to reduce the Nile's water supply and, as far as it is struggling with energy shortages, to look for other alternatives. As a result of water management on the one hand, and climate change on the other, the role of water will be appreciated, and it will lead to further conflicts in the future.

The Grand Renaissance Dam is an excellent example of the military and political importance of critical infrastructure protection (including cyber defense), along with the importance of 'traditional' operations'.

\section{BIBLIOGRAPHY}

Bonnyai, T. “A kritikus infrastruktúra védelem elemzése a lakosságfelkészítés tükrében”. PhD thesis. Budapest: National University of Public Service, 2014.

"Communication from the Commission to the Council and the European Parliament: Critical Infrastructure Protection in the fight against terrorism: COM/2004/0702". European Union. 2004. https://eur-lex.europa.eu/legal-content/EN/TXT/PDF/?uri=CELEX:52004DC0702\&from=en, Accessed on 30 July 2019.

Crabités, P. “The Nile Waters Agreement”. Foreign Affairs 8/1. 1929. 145-149. DOI:10.2307/20028752

"Egypt population". Worldometers. http://www.worldometers.info/world-population/egypt-population/, Accessed on 7 Aug 2019.

"Egypt's limited military options to stop an ethiopian dam project". STRATFOR. 10 Jun 2013. https://worldview.stratfor.com/article/egypts-limited-military-options-stop-ethiopian-dam-project, Accessed on 17 Aug 2019.

“Ethiopia 2030". Populationpyramid.net. https://www.populationpyramid.net/ethiopia/2030/, Accessed on 7 Aug 2019.

"Ethiopia population". Worldometers. http://www.worldometers.info/world-population/ethiopia-population/. Accessed on $30 \mathrm{Jul} 2019$.

22 Bonnyai, T. "A kritikus infrastruktúra védelem elemzése a lakosságfelkészítés tükrében”. PhD thesis. Budapest: National University of Public Service, 2014. 11. 
Havasi, Zs. "Enyhültek a kedélyek a történelmi beruházás körül”. Magyar Nemzet Online, 13 Mar 2015. Https://mno.hu/kulfold/enyhultek-a-kedelyek-a-tortenelmi-beruhazas-korul-1276918, Accessed on 7 Aug 2019.

Kelley, B. M. and Johnson, R. "Stratfor: Egypt is prepared to bomb all of Ethiopa's Nile dams". Business Insider, 13 Oct 2012. http://www.businessinsider.com/hacked-stratfor-emails-egypt-couldtake-military-action-to-protect-its-stake-in-the-nile-2012-10?international=true\&r=us\&ir=t, Accessed on 17 Aug 2019.

Khan, J. "Critical infrastructure protection within NATO". http://www.cipre-expo.com/wp-content/ uploads/2014/02/khan-jahier-nato-cip-within-nato.pdf, Accessed on 30 Jul 2019.

Király A. "Lázadók támadtak az épülő Nílus-gátra Etiópiában”. https://444.hu/2017/03/02/lazadok-tamadtak-az-epulo-nilus-gatra-etiopiaban, Accessed on 17 Aug 2019.

Mason A. "The incredible story of the dambusters raid". Imperial War Museums. 5 Jan 2018. https:// www.iwm.org.uk/history/the-incredible-story-of-the-dambusters-raid, Accessed on 30 Jul 2019.

Molnár, Cs. “A Nagy Reneszánsz Gát”. https://molnarcsaba.wordpress.com/2018/03/22/a-nagy-reneszansz-gat/, Accessed on 3 Aug 2019.

Mondal H. A., Bryan, E., Ringler, C., Mekonnen, D. and Rosegrant, M. "Ethiopian energy status and demand scenarios: prospects to improve energy efficiency and mitigate GHG emissions". Energy 149. 2018. 161-172. DOI:10.1016/j.energy.2018.02.067

Monteiro A. and Thukwana, N. "IMF sees Ethiopia beating Ghana as fastest-growing Africa economy”. Bloomberg. 17 Apr 2018. https://www.bloomberg.com/news/articles/2018-04-17/ethiopiapips-ghana-as-africa-s-fastest-growing-economy-for-imf, Accessed on 30 Jul 2019.

Mules, I. "Ethiopia, Egypt, Sudan make slow progress in Nile dam row". Deutsche Welle. https://www. dw.com/en/ethiopia-egypt-sudan-make-slow-progress-in-nile-dam-row/a-52015611, Accessed on 7 Aug 2019.

"Nile River". In Encyclopedia Britannica. https://www.britannica.com/place/nile-river, Accessed on 3 Aug 2019.

"Sudan population". Worldometers. http://www.worldometers.info/world-population/sudan-population/ Accessed on 7 Aug 2019. 